\title{
ISSUES OF SCIENTIFIC PARADIGMS IN MODERN LINGUISTICS
}

\author{
O. V. BABENKO, PhD in Philology, Associate Professor, \\ National University of Life and Environmental Sciences of Ukraine \\ E-mail: olena14babenko@ukr.net \\ ORCID: 0000-003-0379-4769
}

Ye. A. KUDRITSKAYA, Master of Arts, M.A., Lecturer, Graybridge Malkam School (Ottawa, ON, Canada)

\begin{abstract}
The overall cognitive picture deals with the fact that the subject creates a picture of the world, coordinates individual cognitive acts and expands constantly the sphere of application of these acts. The article highlights the evolution of scientific paradigms in modern science, in particular linguistics, analyzes the polyparadigmatic and integrative nature of modern linguistic studies, which are impossible without a unity of the issues of consciousness, language system, culture and society. Analyzing various scientific paradigms, we state the change of the categorical apparatus and research methods, their evolutionary content-based complication.
\end{abstract}

Keywords: scientific paradigms, approaches, classification, language system, evolution, polyparadigmality, integrativity

Introduction. The modern linguistics is an internally dynamic and quickly expanding space. It transforms rigid boundaries of humanities and social sciences. This expansion led to the formation of new linguistic directions and new paradigms.

Recent research and publications. In the book "The structure of scientific revolutions" (1962) Thomas S. Kuhn, an American scientist, developed a concept of the scientific community as a logical subject of scientific activity. The scientific community by $T$. Kuhn has a unified system of standards - a paradigm - that a researcher can accept without any evidence.

A paradigm is a scientific achievement recognized by all members of the scientific community and a model for a problem statement and solution.

$\mathrm{T}$. Kuhn narrows the concept of paradigm to exemplary achievements of the past and introduces a new concept "disciplinary matrix", by which he means the entire set of beliefs, values and techniques shared by the members of the community. In fact, this new term substitutes the original concept of a paradigm [8, p.153].

Although T. Kuhn was unable to explain the mechanism for the formation of new theories and the interaction of ordinary and extraordinary science, his concept of changing scientific paradigms made a significant contribution to the history and philosophy of science.

Simultaneously with the T. Kuhn's paradigmatic studies in America, PaulMichel Foucault's epistemological direction of is developed in France. According to M. Foucault, the emergence and development of various theories and hypotheses is determined by the historically changing prisms of vision of natural and social processes. M. Foucault calls these prisms of visions epistemes. It is not difficult to notice a certain similarity between T. Kuhn's paradigms of knowledge and M. Foucault's epistemes.

"Episteme" is a philosophical term derived from the Ancient Greek word 


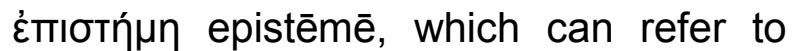
knowledge, science or understanding, and

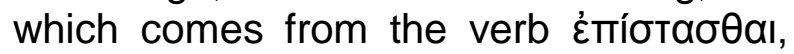
meaning "to know, to understand, or to be acquainted with".

The purpose of the article is to overview current approaches to the concept "scientific paradigms" in the humanitarian sciences in terms of their evolutionary and controversial issues.

While writing the paper, general scientific and linguistic methods have been used such as analysis, synthesis, a comparative and historical method.

Results. In the second half of the XXth century, in connection with the development of the history of science, another general scientific notion was formulated $-a$ style of thinking, understanding of the world. This concept was used along with T. Kuhn's paradigm and M. Foucault's episteme [8, p.214].

By style of thinking M. Born, a German scientist, understands "general tendencies of thought, which are changed very slowly and form certain philosophical periods of specific ideas for them in all areas of human activity, including science" [1, p.232].

The processes of changing of scientific knowledge and the formation of new theories got their further development in the concept of the research programs of I. Lakatos, the English philosopher of Hungarian origin. He proposed a research program as a basic unit for the development of scientific knowledge [9, p.101].

It happened so that the concept "a scientific paradigm" in its original interpretation became the most popular.

In fact, under the paradigm in linguistics, we understand a certain approach, theory or method of linguistic research that is widely recognized in the linguistic community. T. Kuhn's ideas had a great influence on the historiography of linguistics.
It makes sense to emphasize Noam Chomsky's groundbreaking contribution to linguistic theory. His most famous work, "Syntactic Structures" (1957), had a tremendous influence on the development of the science of language. The linguist Noam Chomsky's critical review of Skinner's theory of "verbal behaviour" in 1959 showed that it could not properly account for human language acquisition [7, p.67]. It was one of several triggers for a paradigm shift that by the mid-1960s became the "cognitive revolution," which compellingly argued against behaviourism and led to the development of cognitive science. A lot of scientists spoke about "Chomsky revolution" in linguistics (a change in the scientific paradigm in terms of Kuhn). It introduced the idea of transformational generative grammar.

Chomsky's theory is biolinguistic. It deals with language acquisition in the structures of the brain. He talks of those theoretical structures, responsible for reproducing accurate syntax, as a metaphorical "language acquisition device" (LAD), a hardwired faculty that separates the human brain from that of a dog or cat [6].

Chomsky's theory has little to do with the content of language, but rather with its structure, which he says is universally encoded in our neural architecture.

Chomsky's theory was revolutionary in large part because it was testable. It's a compelling research that just might anticipate the discovery of a physical Language Acquisition Device, or its neurobiological equivalent, in every human brain [6].

According to other linguists, the first truly scientific paradigm (comparativehistorical) appeared in linguistics at the beginning of the XIX-th century. However, this concept came into being only a century later. As for the number of paradigms in linguistics, this issue remains open. Three scientific paradigms are traditionally distinguished: comparative-

(C) O.V.Babenko

«International journal of philology» | «Міжнародний філологічний часопис» Vol. 10, № 2, 2019 
historical, systemic-structural and anthropocentric.

The comparative-historical paradigm was the first paradigm in linguistics. In the systemic-structural paradigm, attention was focused on the object, thing, name, therefore the word was in the center of attention. F. Saussure considered the language "in itself and for itself" [5, p.143].

The crisis of isolationist notions has led linguistics to the need to learn a language in the whole diversity of its external relations, with a person, culture and society. Anthropocentrism has become a feature of modern linguistic researches.

Yu. N. Karaulov (1987) writes about historical, psychological, systemicstructural and social scientific linguistic paradigms. Within the framework of the social (communicative) paradigm, a number of areas are singled out: anthropocentric, sociolinguistic, cognitive, psycholinguistic, linguistic and cultural, that are somehow connected with the text and speech activity [5, p.144].

The famous American scholar in the field of discursive analysis D. Shifrin distinguishes only two paradigms of linguistic knowledge: formal (structural) and functional (interactive) [10, p.68].

Thus, speaking of a paradigm in linguistics, it should be said that most linguists understand it as a method, approach or model of problem statement and solution, that is, as T. Kuhn understood the disciplinary matrix.

Some scientists tend to speak about coexistence of paradigms (a condition of paradigmatic pluralism). The general scientific principle of a complementarity implies coexistence of several interpretation of any multidimensional phenomenon. Besides, in a linguistic historiography there are pendulum-like processes, when some kind of "self-return" of this or that paradigm is often noted. Therefore, a need to establish the most general regularities of science about a language throughout a long period was obvious. It is also required to define a place of each scientific paradigm in the general development of science about a language, to characterize specifics of linguistic schools, their contribution to the development of science in general. The theory of a scientific paradigm possesses of the greatest explanatory force.

A. Zelen'ko in his study, unlike his predecessors, relates the evolution of linguistic paradigms to the evolution of psychological paradigms. They are reflexive, associative, gestalt psychology, behaviorism and J. Piaget's genetic epistemology [2, p.18].

American linguists, being consistent pragmatists, solve linguistic problems not only on the basis of the psychological achievements, but in the harmonious unity of linguistics with psychology and physiology.

While analyzing different linguistic paradigms, we state the change of the categorical apparatus and research methods, their evolution through a systematic content complexity. Meaning is considered to be a core category for analysis of the content of a language of sounds, in particular, vocabulary.

That is why the analysis of linguistic paradigms, on the basis of their integration with psychological paradigms contributes to a deeper interpretation of the meaning of lexemes of all language levels. Moreover, there is a tendency to study the structure of lexeme meanings of all types through the prism of mental, concreteimaginative and emotive components.

Solution of the problems of some language origin and its meaning is realized on the macro-structural and microstructural levels and is based on the general laws of formation of language systems. This multidisciplinary approach can't be imagined without the involvement of philosophy, history, psychology, demography and archeology. We assume that three components of consciousness

(C) O.V.Babenko

«International journal of philology» | «Міжнародний філологічний часопис» Vol. 10, № 2, 2019 
(mental, emotive and volitional) are reproduced in a meaning as a category of information. Indeed, the evolution of linguistic paradigms demonstrates this postulate.

Comparative-historical linguistics has become an extensive continuation of the methodology for analyzing the descriptive paradigm. Researchers were focused on indivisible units of the language system, mainly on the means of expression.

Comparative linguistics deals with synchrony and diachrony in the sphere of language functioning. It researches microstructural, intrastructural, extralinguistic aspects of language identifying the inner form (etymological meaning) of the word and a language model of the world, which are based on the reconstruction of the family tree of the Indo-European language family.

In modern linguistic studies E. S. Kubryakova emphasizes the following four fundamental principles for all schools:

1) expansionism, which is manifested in the emergence of linguistics in connection with other sciences, as well as in the integration of several related sciences and the consolidation of a separate major science;

2) anthropocentrism, according to which scientific objects are studied from the standpoint of their role for a person;

3) functionalism (or neofunctionalism), in which the study of the functions of the object becomes the central problem of science;

4) The principle of explanation ensures the adequacy of knowledge of both sides of the language (external and internal) [3, p.234].

Explanation is interpreted as a tendency of modern linguistics to find a definite explanation for the internal aspects of the language. This principle is realized through the interaction of expansionism and anthropocentrism. This principle indicates the transition from "linguistics" to "why-linguistics" and assumes the adequacy of knowledge of both the formal and the content sides of the language. Whereas linguistic expansionism is closely related to an effort to find every linguistic phenomenon a reasonable explanation through anthropocentrism and functionalism.

By E. Kubryakova's opinion this strategy helps to explain the role of the human factor in the language and the fulfillment of certain functions by the language [3, p. 227].

Conclusions and research prospects. Thus, a paradigm is a scientific achievement and a model for a problem statement and solution. Linguistic paradigms in the XIX-th century helped to extend the object of study horizontally and then scholars started using paradigms to do researches in depth (vertically).

Under the paradigm in linguistics, we understand a certain approach, theory or method of linguistic research that is widely recognized in the linguistic community.

In the linguistic community, due to the complexity of the object of study, linguistics itself by definition is polyparadigmatic and integrative.

From the standpoint of mentioned above statements, language must be studied addressing simultaneously to consciousness, language system, culture and society.

Psychological paradigms are tightly connected with the evolution of linguistic paradigms and prove two main features of modern science -polyparadigmality and integrativity.

Perspectives in further development we see in implementation, first of all, genetic epistemology. 


\section{Список використаних джерел}

1. Борн М. Состояние идей в фризике // Физика в жизни моего поколения (пер. с англ). М.: Иностр. лит., 1963. С. 226-251.

2. Зеленько А. Еволюція категорії значення у структурі різних лінгвістичних парадигм. Лінгвістичні студії. 2013. Вип. 27. С. 15-23.

3. Кубрякова Е. С. Эволюция лингвистических идей во второй половине $X X \quad$ века (опыт парадигмального анализа) // Язык и наука конца XX века. М.: РГГУ, 1995. С. 144-238.

4. Фуко М. Слова и вещи (археология гуманитарных наук). СПб.: A-cad, 1994. 406 c.

5. Хомутова Т. Н. Научные парадигмы в лингвистике // Вестник Челябинского государственного университета. 2009. № 35 (173). Филология. Искусствоведение. Вып. 37. C. 142-151.

6. A Brief Animated Introduction to Noam Chomsky's Linguistic Theory, Narrated by The X-Files' Gillian Anderson.URL:

http://www.openculture.com/2015/02/wha t-makes-us-human-chomsky-lockemarx.html

7. Chomsky N. Syntactic structures. The Hague: Mouton, 1957.117 p.

8. Kuhn T. S. The Structure of Scientific Revolutions. 2-nd edn. (First published in 1962). Chicago, IL: Univ. of Chicago Press , 1970. P. 175

9. Lakatos J. Falsification and the Methodology of Scientific Research Programs // Criticism and the Growth of Knowledge / ed. by J. Lakatos and A. Musg rave. Cambridge, UK : Cambridge Univ. Press, 1970. P. 91-195.

10. Schiffrin D. Approaches to Discourse. Cambridge, MA: Blackwell Publishers Inc., 1995. 470 p.

\section{References}

1. Born, M. (1963). Sostoyanie idey v fizike [The state of ideas in physics]. Fizika $v$ zhizni moego pokoleniya [Physics in the life of my generation] (translation from English). Moscow: Inostranaya literature, 226-251.

2. Zelenko, A. (2013). Evoliutsiia katehorii znachennia u strukturi riznykh linhvistychnykh paradyhm [Evolution of category values in the structure of various linguistic paradigms]. Linhvistychni studii. Volume. $27 . \quad$ S. 15-23. URL: http://nbuv.gov.ua/UJRN/lingst_27_3.

3. Kubryakova, E. S. (1995). Evolyutsiya lingvisticheskih idey vo vtoroy polovine $X X$ veka (opyit paradigmalnogo analiza) [The evolution of linguistic ideas in the second half of the twentieth century (the experience of paradigmatic analysis)]//Language and science at the end XX century. Moscow: RGGU.

4. Fuko, M. (1994). Slova i veschi [Words and things] (arheologiya gumanitarnyih nauk [Archeology of the Humanitarian]. Saint Petersburg: Academy, 406.

5. Khomutova, T. N. (2009). Nauchnyie paradigmyi $\mathrm{v}$ lingvistike [Scientific paradigms in linguistics]. Scientific Herald of Chelyabinsk State University, 35 (173). Philology. Art history. Issue, 37, 142-151.

6. A Brief Animated Introduction to Noam Chomsky's Linguistic Theory, Narrated by The X-Files' Gillian Anderson.URL:

http://www.openculture.com/2015/02/wha t-makes-us-human-chomsky-locke-

marx.html

7. Chomsky, N. (1957).Syntactic structures. The Hague: Mouton, 117.

8. Kuhn, T. S. (1962). The Structure of Scientific Revolutions. 2-nd edn. (First published in 1962). Chicago, IL: Univ. of Chicago Press, 175.

9. Lakatos, J. (1970). Falsification and the Methodology of Scientific Research Programs // Criticism and the Growth of 
Knowledge / ed. by J. Lakatos and A. Musg rave. Cambridge, UK : Cambridge Univ. Press, 91-195.
10. Schiffrin,

D. Approaches to Discourse. Cambridge, MA: Blackwell Publishers Inc., 470.

\section{ПРОБЛЕМАТИКА НАУКОВИХ ПАРАДИГМ У СУЧАСНІЙ ЛІНГВІСТИЦІ О. В. Бабенко}

Анотація. Загальна картина пізнання полягає в тому, що суб'єкт активно конструює картину світу, координує між собою окремі пізнавальні акти та постійно розширює сореру застосування цих актів. У статmі розглянуто еволюцію наукових парадигм у сучасній науці, зокрема лінгвістиці, проаналізовано поліпарадігмальний та інтегративний характер сучасних лінгвістичних досліджень, які неможливі без єдності розгляду питань свідомості, мовної системи, культури та суспільства. Аналізуючи різні наукові парадигми, констатуємо зміну категоріального апарату та методик дослідження, їх еволюційне змістовне ускладнення.

Ключові слова: наукові парадигми, підходи, класифікація, мовна система, еволюція, поліпарадигмальність, интегративність 